\title{
STUDY OF SOCIO-DEMOGRAPHIC CHARACTERISTICS OF PERSONS ATTENDING AN INTEGRATED COUNSELING AND TESTING CENTRE AT GWALIOR
}

\author{
Subodh Mishra ${ }^{1}$, Akshat Pathak ${ }^{2}$, Mahendra Chouksey ${ }^{3}$
}

${ }^{1}$ Deputy Director, Medical Education Department, Bhopal, Madhya Pradesh.

${ }^{2}$ Post Graduate Student in Community Medicine, L. N. M. C, Bhopal, Madhya Pradesh.

${ }^{3}$ Assistant Professor, Department of Community Medicine, G. R. M. C, Gwalior, Madhya Pradesh.

\section{ABSTRACT}

\section{BACKGROUND}

India is one of the largest and most populated countries in the world, with over 1.2 billion inhabitants. HIV/AIDS spread in such a country is a big challenge for health professionals.

\section{OBJECTIVES}

To study socio-demographic characteristics of ICTC attendees.

\section{MATERIALS AND METHOD}

A cross-sectional study among 244 attendees of ICTC using a pretested semi-structured schedule regarding socio-demographic variables.

\section{RESULTS}

Majority of the persons were Hindu (96.72\%) and 47.95\% belonged to SC category. Most of them (53.69\%) resided in rural area. Majority of study subjects were found non-migrant (91.39\%). Majority (79.1\%) of subjects were married. More than one third of the study subjects were illiterate. The most common source of income for males (38.61\%) was semi-skilled occupation. Among females $72.09 \%$ were housewives. Majority (39.75\%) of study subjects belonged to socio-economic status class IV, while only $5.33 \%$ belonged to class I.

\section{CONCLUSION}

Present study was conducted to know socio-demographic characteristics of attendees at ICTC Centre of G. R. Medical College Gwalior with a view to find out population, which could not be benefitted from taking ICTC services so that those groups be mobilized by way of policy formulation to attend ICTC, which is important for their health wellbeing as regards to prevention and treatment of HIV/AIDS. Study revealed that Education, Women Empowerment. Social Mobilization and IEC are few key issues, which deserve to be addressed for an effective coverage of at risk population.

\section{KEYWORDS}

ICTC, HIV/AIDS, Socio Economic Status.

HOW TO CITE THIS ARTICLE: Mishra S, Pathak A, Chouksey M. "Study of socio-demographic characteristics of persons attending an integrated counseling and testing centre at Gwalior." Journal of Evolution of Medical and Dental Sciences 2015; Vol. 4, Issue 104, December28; Page: 16957-16959, DOI: 10.14260/jemds/2015/2558

\section{INTRODUCTION}

AIDS has emerged as one of the most serious public health problem in the world. According to UNAIDS/WHO estimates there are 38.6 million people living with HIV worldwide. ${ }^{1}$ India has a sharp increase in the estimated number of HIV infection from a few thousand in early 1990s to steeply increasing to between 2 and 3.1 million which comes to 2.5 million. ${ }^{2}$ Factors that contribute to the spread of HIV in other low income countries such as internal migration of large groups of men (Truck drivers, minors, military), civil instability, drug use, untreated sexually transmitted infections, poor literacy, gender inequality and endemic poverty are also present in India. ${ }^{3}$

Integrated voluntary counseling and testing for HIV is a cost effective intervention in preventing HIV transmission and it has become an integral part of HIV prevention programmes.

Financial or Other, Competing Interest: None.

Submission 17-12-2015, Peer Review 18-12-2015,

Acceptance 24-12-2015, Published 28-12-2015.

Corresponding Author

Dr. Subodh Mishra

Department of Community Medicine,

Deputy Director, Medical Education Department,

Bhopal, Madhya Pradesh.

E-mail: drsubodhmishragwalior@gmail.com

DOI:10.14260/jemds/2015/2558
The integrated counseling and testing centres- ICTC is an entry point to care, which provides people with an opportunity to learn and accept their HIV serostatus in a confidential environment. 4

\section{MATERIAL AND METHODS}

This study was conducted in G. R. Medical College, Gwalior. It is an institution based cross sectional descriptive study done at ICTC associated with Medical College, Gwalior. Nonprobability sampling method was adopted. An in-depth interview using a pretested semi structured questionnaire was conducted for the collection of information. Total duration of study was 01 Year. Study permission was obtained from competent authority. The study did not require any invasive or non-invasive diagnostic procedure nor withholding any prescribed drug under treatment.

Inclusion Criteria-Study subjects who were willing to participate in the study and willing to offer their consent. Ethical Consideration - The study did not require any invasive or non-invasive diagnostic procedure, nor withholding any prescribed drug as per treatment protocol. Selection of Subjects-244 subjects was included in the study out of 360 persons who attended ICTC during the course of study because rest of the persons could not fulfil inclusion criteria. Criteria for socio-economic status-Modified B. G. Prasad's Classification, i.e. per capita monthly income=Total monthly 
income of family divided by Total members of the family. Statistical test-Study was an Institutional based crosssectional descriptive study. After taking interview from the study population, all proformas were collected and compiled and were analysed in pursuance of defined objectives by using statistical methods like percentage and proportions by using suitable statistical software.

\section{RESULTS AND DISCUSSION}

\begin{tabular}{|c|c|c|c|c|}
\hline $\begin{array}{l}\text { Sl. } \\
\text { No. }\end{array}$ & Particulars & $\begin{array}{c}\text { Male } \\
\text { n(158) } \\
\%(64.75)\end{array}$ & $\begin{array}{c}\text { Female } \\
\text { n(86) } \\
\%(35.24)\end{array}$ & $\begin{array}{c}\text { Total } \\
(244) \\
(\%)\end{array}$ \\
\hline 1 & $\begin{array}{c}\text { Religion } \\
\text { Hindu } \\
\text { Muslim }\end{array}$ & $\begin{array}{c}153(96.83) \\
5(3.16)\end{array}$ & $\begin{array}{c}83(96.51) \\
3(3.5)\end{array}$ & $\begin{array}{c}236(96.72) \\
8(3.28)\end{array}$ \\
\hline 2 & $\begin{array}{c}\text { Caste } \\
\text { General } \\
\text { SC } \\
\text { ST } \\
\text { OBC }\end{array}$ & $\begin{array}{c}57(36.07) \\
71(44.94) \\
7(4.430 \\
23(14.56) \\
\end{array}$ & $\begin{array}{c}24(27.91) \\
46(53.49) \\
4(4.65) \\
12(13.95) \\
\end{array}$ & $\begin{array}{c}81(33.2) \\
117(47.95) \\
11(4.51) \\
35(14.34) \\
\end{array}$ \\
\hline 3 & $\begin{array}{c}\text { Residence } \\
\text { Rural } \\
\text { Urban }\end{array}$ & $\begin{array}{l}81(51.26) \\
77(48.73)\end{array}$ & $\begin{array}{l}50(58.14) \\
36(41.86)\end{array}$ & $\begin{array}{l}131(53.69) \\
113(46.31)\end{array}$ \\
\hline 4 & $\begin{array}{c}\text { Migratory } \\
\text { Status } \\
\text { Migrant } \\
\text { Non-Migrant } \\
\end{array}$ & $\begin{array}{c}21(13.29) \\
137(86.71)\end{array}$ & $\begin{array}{c}0(0) \\
86(100)\end{array}$ & $\begin{array}{c}21(8.61) \\
223(91.39)\end{array}$ \\
\hline 5 & $\begin{array}{l}\text { Marital Status } \\
\text { Un-Married } \\
\text { Married } \\
\text { Widowed/Wi } \\
\text { dower }\end{array}$ & $\begin{array}{c}27(17.1) \\
131(82.91) \\
0(0)\end{array}$ & $\begin{array}{c}20(23.25) \\
62(72.09) \\
4(4.65)\end{array}$ & $\begin{array}{c}47(19.26) \\
193(79.1) \\
4(1.64)\end{array}$ \\
\hline
\end{tabular}

Majority of the persons were Hindu (96.72\%) and $47.95 \%$ belonged to SC category. Most of them (53.69\%) resided in rural area. Majority of study subjects were found non-migrant (91.39\%). Majority (79.1\%) of subjects were married.

\begin{tabular}{|c|c|c|c|c|}
\hline $\begin{array}{l}\text { Sl. } \\
\text { No. }\end{array}$ & Particulars & $\begin{array}{c}\text { Male } \\
(158)(\%)\end{array}$ & $\begin{array}{c}\text { Female } \\
(86)(\%)\end{array}$ & $\begin{array}{c}\text { Total } \\
(244)(\%)\end{array}$ \\
\hline 1 & $\begin{array}{c}\text { Education } \\
\text { Illiterate } \\
\text { Up to } \\
\text { Primary } \\
\text { Up to Middle } \\
\text { Up to High } \\
\text { School } \\
\text { Up to Higher } \\
\text { Sec } \\
\text { Graduate and } \\
\text { Post } \\
\text { Graduate } \\
\text { Others* }\end{array}$ & $\begin{array}{c}48(30.38) \\
12(7.59) \\
11(6.96) \\
31(19.62) \\
28(17.72) \\
24(15.19) \\
4(2.53)\end{array}$ & $\begin{array}{c}39(45.35) \\
9(10.46) \\
5(5.81) \\
9(10.46) \\
14(16.27) \\
8(9.3) \\
2(2.32)\end{array}$ & $\begin{array}{c}87(35.65) \\
21(8.60) \\
16(6.56) \\
40(16.39) \\
42(17.21) \\
32(13.11) \\
6(2.46)\end{array}$ \\
\hline 2 & $\begin{array}{c}\text { Occupation } \\
\text { Un-Skilled } \\
\text { Semi-Skilled } \\
\text { Skilled } \\
\text { Professionals } \\
\text { Housewife } \\
\text { Clerical } \\
\text { Others** }\end{array}$ & $\begin{array}{c}21(13.29) \\
61(38.61) \\
28(17.72) \\
4(2.53) \\
0(0) \\
23(14.56) \\
21(13.29)\end{array}$ & $\begin{array}{c}2(2.32) \\
5(5.81) \\
0(0) \\
0(0) \\
62(72.09) \\
0(0) \\
17(19.77)\end{array}$ & $\begin{array}{c}23(9.42) \\
66(27.05) \\
28(11.47) \\
4(1.64) \\
62(25.41) \\
23(9.43) \\
38(15.57)\end{array}$ \\
\hline & Educ & and $O c$ & on $(N=2$ & \\
\hline
\end{tabular}

* Others-Education-Pre-School

**Others-Occupation-Students, Unemployed.
More than one-third of the study subjects were illiterate. The most common source of income for males (38.61\%) was semi-skilled occupation. Among females $72.09 \%$ were found housewives.

\begin{tabular}{|c|c|c|c|c|}
\hline $\begin{array}{l}\text { Sl. } \\
\text { No. }\end{array}$ & Particulars & $\begin{array}{c}\text { Male } \\
(158)(\%)\end{array}$ & $\begin{array}{l}\text { Female } \\
(86)(\%)\end{array}$ & $\begin{array}{l}\text { Total } \\
(244)(\%)\end{array}$ \\
\hline 1 & $\begin{array}{c}\text { Socio- } \\
\text { Economic } \\
\text { Status } \\
\text { Class-I } \\
\text { Class-II } \\
\text { Class-III } \\
\text { Class-IV } \\
\text { Class-V }\end{array}$ & $\begin{array}{c}9(5.7) \\
26(16.45) \\
31(19.62) \\
60(37.97) \\
32(20.25)\end{array}$ & $\begin{array}{c}4(4.65) \\
11(12.79) \\
24(27.9) \\
37(43.02) \\
10(11.63)\end{array}$ & $\begin{array}{c}13(5.33) \\
37(15.16) \\
55(22.54) \\
97(39.75) \\
42(17.21)\end{array}$ \\
\hline \multicolumn{5}{|c|}{$\begin{array}{c}\text { Table 3: Distribution of Subjects according to } \\
\text { Socio-economic status. }{ }^{5}\end{array}$} \\
\hline
\end{tabular}

Majority (39.75\%) of study subjects belonged to socioeconomic status class IV, while only $5.33 \%$ belonged to class I.

\section{DISCUSSION}

The present study highlights the fact that males contributed to $64.75 \%$ of the persons who attended ICTC with $35.24 \%$ being the females. These figures are slightly lower than the national average of $38.4 \%$ for females. This gender ratio of attendance rates was in accordance with national figures and indicates the existence of some barriers preventing the access of females. Considering the national data based on information collected from sentinel surveillance sites women are less likely to visit an antenatal clinic/testing centres if they are older, have high parity, are illiterate or are poor. ${ }^{6}$

It was observed that majority of clients, i.e. $52.45 \%$ were from schedule caste/schedule tribes; $56.96 \%$ persons belonged to low socio-economic status (class-IV and V). The majority of subjects were illiterate $(35.65 \%)$ and $16.39 \%$ had education up to $10^{\text {th }}$ standard. In the study conducted by Sharma et al. ${ }^{7}$ at Ahmadabad $38.5 \%$ of ICTC attendees had education up to $10^{\text {th }}$ standard. G. K. Jordar et al. ${ }^{8}$ in his study found that $33.2 \%$ attendees were illiterate. In this study less number of attendees were in the higher education groups $(13.11 \%)$. It seems that education has a positive impact as the people who are well educated are more receptive to information, education and communication and are amenable to interventions.

With regards to occupation most of the male attendees were semi-skilled (38.61\%) and skilled (17.72\%) workers. Most of the females were housewives (72.09\%). G. K. Jordar et al. ${ }^{8}$ in his study found that $28.6 \%$ attendees were unskilled workers. In this study group $8.61 \%$ attendees were migrants. Long distance vehicle drivers and labourers are a highly mobile group, in whom having multiple sex partners is quite common.

\section{CONCLUSION}

Present study was conducted to know socio-demographic characteristics of attendees at ICTC Centre of G. R. Medical College, Gwalior. Majority of attendees (83.2\%) were from age group of 15-45 years, which is the most sexually active age group and the case load in ICTC was contributed mainly by males (64.75\%) as compared to females (35.24\%). Study revealed that $33.2 \%$ attendees belong to General Category. Majority (39.75\%) belonged to low socio-economic status, i.e. class-IV. More than one-third attendees were illiterate (35.65) and very few attendees were from higher education group. Majority of attendees were non-migrant (91.39), while migrant attendees were less (8.61\%). 
Most of the male attendees were semi-skilled (38.61\%), while skilled workers were $17.72 \%$. Majority of the females were housewives (72.09\%).

\section{REFERENCES}

1. WHO/UNAIDS AIDS Epidemic Update, December 2007. Available from:www.unaids.org/en/HIV-data.

2. Lal S. Surveillance of HIV/AIDS in India (Editorial). Indian Journal of Community Medicine, 2003;XXVIII (1):3-9.

3. Centres for Disease Control and Prevention (CDC). The Global HIV and AIDS Epidemic. MMWR Morb Mortal Wkly Rep 2001;50:434-9.
4. Campbell CJ, Marum ME, Alwano-Edyegu M, et al. The role of HIV counseling and testing in the developing world. AIDS Educ Prev. 1997;(suppl):92-104.

5. Kumar P. Social classification-Need for constant updating. Indian J Community Med 1993;18:60-1.

6. Kumar R, Jha P, Arora P, Mony P, Bhatia P, Millson P, et al. Trends in HIV-1 in young adults in South India from 2000 to 2004 : a prevalence study.

The Lancet 2006;367:1164-72.

7. Sharma R. Profile of attendee for voluntary counseling and testing in the ICTC at Kesar SAL Medical College, Ahmadabad. Indian J Sex Transm Dis; 30:31-6, 2009.

8. Jordar GK, Sarkar A, Chatterjee C, Bhattacharya RN, Sarkar S, Banerjee P. Profile of attendees in VCTC of North Bengal Medical College in Darjeeling District of West Bengal. Ind J of Community Med: 31:237-40, 2006. 